OPEN ACCESS

Edited by:

Bin Yang,

Xi'an University of Architecture and

Technology, China

Reviewed by:

Giuseppe Riccio,

University of Naples Federico II, Italy

Giacomo Salvadori,

University of Pisa, Italy

*Correspondence:

Carolina Piña Ramírez

carolina.pina@upm.es

Specialty section: This article was submitted to

Indoor Environment,

a section of the journal

Frontiers in Built Environment

Received: 21 January 2021

Accepted: 27 July 2021

Published: 26 August 2021

Citation

Aguilera Benito P, Piña Ramírez C, Viccione $G$ and Lepore E (2021)

Ventilation for Residential Buildings:

Critical Assessment of Standard

Requirements in the COVID-19

Pandemic Context.

Front. Built Environ. 7:656718.

doi: 10.3389/fbuil.2021.656718

\section{Ventilation for Residential Buildings: Critical Assessment of Standard Requirements in the COVID-19 Pandemic Context}

\author{
Patricia Aguilera Benito ${ }^{1}$, Carolina Piña Ramírez ${ }^{2 \star}$, Giacomo Viccione ${ }^{3}$ and Ester Lepore ${ }^{3}$ \\ ${ }^{1}$ Department of Architectural Constructions and their Control, School of Building Construction, Technical University of Madrid, \\ Madrid, Spain, ${ }^{2}$ Building Technology Department, School of Building Construction, Technical University of Madrid, Madrid, Spain, \\ ${ }^{3}$ Department of Civil Engineering, University of Salerno, Fisciano, Italy
}

After the arrival of a new airborne virus to the world, science is aiming to develop solutions to withstand the spread and contagion of SARS-CoV-2. The most severe among the adopted measures is to remain in home isolation for a significant number of hours per day, to avoid the spreading of the infection in an uncontrolled way through public spaces. Recent literature showed that the primary route of transmission is via aerosols, especially produced in poorly ventilated inner spaces. Spain has reached very high levels concerning contagion rates, accumulated incidence, or number of hospitalizations due to COVID-19. Therefore, this article aims to develop a quantitative and qualitative analysis of the requirements established in Spain, with respect to the European framework in reference to ventilation parameters indoors. The different parameters that serve as calculation for the ventilation flow in homes are analyzed to this aim. Results show that the criteria established in the applicable regulations are insufficient to ensure health and avoid contagion by aerosols indoors.

Keywords: ventilation, indoor air quality, COVID-19, aerosols, Spain

\section{INTRODUCTION}

At the end of 2019, a new airborne virus, "COVID-19," was first identified in Wuhan, China. The quick spreading soon turned into a worldwide pandemic, showing that people do not have immunity against it, along with a high level of contagion and a significant mortality rate (Li et al., 2020). The first cases were registered in Europe at the end of January (Spiteri et al., 2020). The first 100 infections are counted as day zero, which in Spain were reached on March 5, 2020 (Domínguez et al., 2020; Glass, 2020). From that moment on, different governments have taken measures such as the closure

Abbreviation: $\mathrm{ACH}$, air changes per hour; $\mathrm{CO}$, carbon monoxide; $\mathrm{CO}_{2}$, carbon dioxide; COVID-19, coronavirus disease 2019 CTE, technical code of the building; EN, European Norm; DB HS, basic document on salubrity; IAQ, indoor air quality; IEQ, indoor environmental quality; IEQ cat, indoor environmental quality category for design; NOX, oxides of nitrogen; ns, crowding index per unit area; O3, ozone; OMS (WHO), World Health Organization; PM, particulate matter; ppm, parts per million; qB, ventilation rate for building materials; Qop, specific external air flow per person; qp, ventilation rate for people; qv, minimum flow for housing; $\mathrm{R} / \mathrm{h}$, air renewal per hour; SIMA, Italian Society of Environmental Medicine; $\mathrm{SO}_{2}$, sulfur dioxide; UNE, a Spanish standard; UNESCO, United Nations Educational, Scientific and Cultural Organization; UNI, Italian National Unification Body. 
of airports (Borrelli, 2020), schools, commercial activities, restaurants, etc. (Ordinanza del Ministro della salute 30 gennaio 2020, 2020; Delibera del Consiglio dei Ministri 31 gennaio 2020, 2020; Ley 33/2011 de 4 de octubre, 2011).

With the arrival of the COVID-19 pandemic, people worldwide have experienced remarkable changes to the way they live their lives at home. Suddenly, the society has had to face involuntary confinement, from one day to the next, and been obligated to stay indoors much longer than usual, sharing spaces no matter occupants are of the same nuclear family or not. Workers have had to start working remotely from buildings, and both children and teenagers have had to follow and deal with online lessons (Elnikova et al., 2020; Voss and Wittwer, 2020).

Humankind is facing issues related to the ongoing pandemic that can definitely affect the quality of life, e.g., considering the importance of ventilation on the air distribution, determining comfort and health in indoor environments (Gilani et al., 2016; Hamdy and Mauro, 2019). According to various studies, contagion is due to aerosols' exposure that conveys the virus through the environment, and this risk can be minimized with clean air derived from good indoor ventilation (Zoran et al., 2020; CCAES, 2020; Dati aggregati quotidiani Regioni / PPAA, 2021; Urrutia-Pereira et al., 2020; Filippini et al., 2020; Baldasano, 2020). A well-ventilated home is beneficial to health. The air circulation allows it to be oxygenated, which facilitates the expulsion of dust particles and mites, regulates the humidity of the environment, and eliminates bad odours. In addition, ultraviolet rays can act against some microorganisms; therefore, if possible, it is also beneficial for sunlight to flood the house. On the contrary, when the house is not well ventilated, one can suffer energy dips, frequent headaches, sleep difficulties, and breathing issues, not to mention the risk of infection in times of pandemic like the one we are experiencing. In addition, poor ventilation fosters the spread of germs, especially in closed and humid environments.

Therefore, the need to improve indoor air quality arises, as it may contain atmospheric pollutants. The latter can be divided, according to their physical nature, into gaseous and particulate matter, and according to their formation, into primary pollutants: sulfur dioxide $\left(\mathrm{SO}_{2}\right)$, nitrogen oxides $\left(\mathrm{NO}_{\mathrm{x}}\right)$, carbon monoxide (CO), and secondary pollutants: ozone $\left(\mathrm{O}_{3}\right)$ and particulate matter (PM) (World Health Organization, 2005; GarciaChevesich et al., 2014; Madureira et al., 2016; Coleman and Meggers, 2018; Ogen, 2020). Electronic noses, shortly e-noses consisting of a sensor array and a pattern recognition algorithm, may be conveniently used as smart devices to monitor indoor air quality in the living environment (Viccione et al., 2012; Sironi et al., 2014; Viccione et al., 2014). However, in order to avoid high concentrations of the abovementioned substances, it is necessary to have good indoor ventilation. Furthermore, the presence of people in confined spaces for a higher number of hours per day may imply an increase in the concentration of $\mathrm{CO}_{2}$ (Giechaskiel, 2020; Rossi et al., 2020). Obviously, with the increase in time spent indoors, the time of use of appliances, lighting, heating, etc., increases, which can also increase the amount of $\mathrm{CO}_{2}$ released (Heinonen et al., 2016; Aguilera et al., 2018).
Indoor heating and cooling yield the primary source of energy consumption, while the use of appliances is the most important factor in terms of $\mathrm{CO}_{2}$ emissions (Jin et al., 2020; Yao et al., 2020). However, healthy environments may be obtained through optimal systems that seek a balance between energy savings and optimal ventilation conditions (Balocco and Leoncini, 2020; Darmanis et al., 2020; De Gaetani et al., 2020; Dudzik, 2020; Lee et al., 2020). According to the "Recommendations of the UNESCO Chair on Health Education and Sustainable Development and the Italian Society of Environmental Medicine (SIMA)," a substantial accumulation of $\mathrm{CO}_{2}$ can cause problems in people with lung conditions. It can also decrease concentration and workers' and students' productivity (Espejo et al., 2020; Gautam, 2020; Pulimeno et al., 2020; Woodby et al., 2020).

An efficient living, work, or study environment is, therefore, a fundamental requirement for building occupants to either live healthy or work productively. Thus, improving indoor air quality can be very important to increase productivity and, moreover, to avoid the spread of the virus (Abuhegazy et al., 2020; Fürhapper et al., 2020; Sun and Zhai, 2020; AguileraBenito et al., 2021). To reduce the likelihood of transmission via air, the WHO recommends a natural ventilation rate of at the least $60 \mathrm{~L}$ per second and per person and at least six air changes per hour (World Health Organization, 2020a; World Health Organization, 2020b). In light of the literature review carried out, some questions can be raised: what are the regulations in Spain and Europe in matter of ventilation parameters? Are indoor environments up to the task of adopting the imposed, yet hopefully transitory, "new way of life"? Can they be considered safe in terms of preventing contagion, safeguarding public health? Also, have them proper ventilation system, according to the new demands in times of pandemic? In the following, we try to address the aboveposed questions.

\section{METHODS}

Due to the importance of ventilation in times of pandemic, this research focuses on the effectiveness of air change in homes, checking whether the corresponding values agree with the new requirements and directives established by laws, to contain spreading contagion. The methodology used for the air quality analysis consists of calculating flow rates and $\mathrm{R} / \mathrm{h}$ of ventilation adopted indoors in Europe and Spain, considering the amount $\mathrm{CO}_{2}$ emitted per person in the framework of the newly issued directives of COVID-19. To verify that the indoor ventilation is still adequate to the new requirements, the existing regulations at the European level are analyzed in comparison to the Spanish regulations regarding the minimum measurements indoors. A regression analysis was carried out to estimate the relationships between the aboveobtained values and those derived with a oneway analysis of variance (ANOVA). This aspect is crucial because the increase of $\mathrm{CO}_{2}$ concentration indoors, where people's breathing and related activities account for a greater share due to the confinement, would imply an insufficient air exchange, raising the risk of SARS-CoV-2 contagion. 
TABLE 1 | Description of the air quality categories in buildings.

\begin{tabular}{|c|c|c|c|c|c|c|}
\hline Category & \multicolumn{2}{|c|}{ Level of expectation } & \multicolumn{4}{|c|}{ Explanation } \\
\hline IEQ । & \multicolumn{2}{|c|}{ High } & \multicolumn{4}{|c|}{ Should be selected for occupants with special needs (children, elderly, and people with disabilities) } \\
\hline IEQ II & \multicolumn{2}{|c|}{ Medium } & \multicolumn{4}{|c|}{ The normal level used for design and operation } \\
\hline IEQ III & \multicolumn{2}{|c|}{ Moderate } & \multicolumn{4}{|c|}{ Will still provide an acceptable environment. Some risk of reduced performance of the occupants } \\
\hline IEQ IV & \multicolumn{2}{|c|}{ Low } & \multicolumn{4}{|c|}{ Should only be used for a short time of the year or in a space with very short time of occupancy } \\
\hline \multicolumn{7}{|c|}{ Source: EN 16798-2: 2019.} \\
\hline \multirow[t]{2}{*}{ Category } & \multicolumn{3}{|c|}{$\begin{array}{l}\text { Total ventilation including } \\
\text { infiltration air (1) }\end{array}$} & $\begin{array}{l}\text { Airflow delivered per } \\
\text { person (2) }\end{array}$ & \multicolumn{2}{|c|}{$\begin{array}{l}\text { Supplied air flow based on indoor air quality } \\
\text { (IAQ) perceived by adapted people (3) }\end{array}$} \\
\hline & $\mathrm{l} / \mathrm{s} \mathrm{m}^{2}$ & \multicolumn{2}{|c|}{ Ach (air changes per hour) } & I s $\mathrm{s}^{-1} \operatorname{pax}^{-1}$ & $q_{p}$ in $I s^{-1} p x^{-1}$ & $q_{p}$ in $I s^{-1} m^{-2}$ \\
\hline I & 0.49 & \multicolumn{2}{|l|}{0.7} & 10 & 3.5 & 0.25 \\
\hline ॥ & 0.42 & \multicolumn{2}{|l|}{0.6} & 7 & 2.5 & 0.15 \\
\hline III & 0.35 & \multicolumn{2}{|l|}{0.5} & 4 & 1.5 & 0.1 \\
\hline IV & 0.23 & 0.4 & & & & \\
\hline
\end{tabular}

TABLE 3 | Minimum flow rate for constant flow ventilation in rooms. Source: CTE HS 3 (Gobierno de España, Ministerio de Fomento, 2019).

Housing type

Minimum flow $q_{v}$ in $I s^{-1}$

\begin{tabular}{ccccc}
\hline & Dry areas & & \multicolumn{2}{c}{ Humid areas } \\
\cline { 3 - 5 } Main bedroom & Rest of bedrooms & $\begin{array}{c}\text { Living room and dining } \\
\text { rooms }\end{array}$ & & Minimum in total \\
8 & - & 6 & 24 & 24 \\
8 & 4 & 8 & 33
\end{tabular}

\section{Regulations Regarding Ventilation}

According to the applicable regulations, the current legislation in Europe and Spain is analyzed to calculate the main parameters needed to maintain a healthy indoor air quality. The factors that most influence health indoor are air renewal per hour and the minimum ventilation flow, as well as the concentration of $\mathrm{CO}_{2}$ indoors. They will be studied according to the different parameters set by the different legislations.

\section{Minimum Required Airflow and Air Renovation per House}

- For Europe:

In Europe, we consider the European standard EN 16798:2019 "Energy performance of buildings: Ventilation for buildings" where the quality of the indoor environment by category (Table 1) is taken into account, as well as the floor area and the people that can be set in case of nonresidential buildings.

The ventilation flow through residential buildings is calculated based on the criteria established for predefined supplied ventilation
TABLE 4 | Design $\mathrm{CO}_{2}$ concentrations for living rooms and occupied rooms.

\begin{tabular}{lcc} 
Category & $\begin{array}{c}\text { Design } \triangle \mathrm{CO}_{2} \text { concentrations } \\
\text { for living rooms (ppm) }\end{array}$ & $\begin{array}{c}\text { Design } \triangle \mathrm{CO}_{2} \text { concentrations } \\
\text { for rooms (ppm) }\end{array}$ \\
\hline I & 550 & 380 \\
\hline II & 800 & 550 \\
\hline III & 1,350 & 950 \\
IV & 1,350 & 950
\end{tabular}

air flow rates: total ventilation for case 1 and supplied air for cases 2 and 3 in residential buildings (Table 2). Finally, the result with the highest value obtained is chosen, this being the most restrictive.

- For Spain:

In Spain, according to CTE HS 3 "Quality of indoor air," the amount of minimum flow in $1 / \mathrm{s}$ depending on the number of dry and humid areas present in the housing is taken into 
consideration (Table 3) (Gobierno de España, Ministerio de Fomento, 2019).

In order to calculate the value of the minimum flow $\mathrm{q}_{\mathrm{v}}$ in $1 \mathrm{~s}^{-1}$, the number of bedrooms present in the housing (admission calculation) and the number of toilets, bathrooms, or kitchens must be considered (extraction calculation). In this way, the final result of the flow of the house will be determined by the highest resulting value, whether of admission or extraction, being the same for both cases so that there are no pressure differences inside the property.

\section{$\mathrm{CO}_{2}$ Concentration per House}

- For Europe:

According to the EN-16798-2 standard, the maximum concentration of $\mathrm{CO}_{2}$ for each of the categories is shown in Table 4 (UNE-EN 15251, 2008), referring to premises in a house and the outdoor concentration.

In addition, UNE 171330-2 shows the inspection procedures for indoor environmental quality. In this sense, the standard indicates a maximum comfort criterion of $500 \mathrm{ppm}$ and a maximum permissible indoor limit value of 2,500 ppm.

\section{- For Spain:}

In Spain, as established by CTE HS 3 "Indoor air quality," it is considered that a sufficient flow of outdoor air must be provided in the living areas of the houses to achieve that, in each area, the average annual concentration of $\mathrm{CO}_{2}$ is less than $900 \mathrm{ppm}$ and that the annual accumulated $\mathrm{CO}_{2}$ that exceeds $1,600 \mathrm{ppm}$ is less than 500,000 ppmh, at the same time (Gobierno de España, Ministerio de Fomento, 2019).

\section{Prescriptions Indicated By the Competent Authorities Due to the Pandemic}

Due to the importance of eliminating the concentration of different pathogens in the air to minimize SARS-CoV-2 infections, different governments have published application guides with restrictions regarding the ventilation flow, air changes per hour, and the maximum concentration of $\mathrm{CO}_{2}$ (ASHRAE Board of Directors, 2020; Bonadonna et al., 2020; Instituto para la diversificación y ahorro de energía, 2020; Rapporto Istituto Superiore della Sanità (ISS), 2020).

In Spain, the government published different manuals on recommendations for ventilation systems based on preventing the spread of COVID-19. With regard to the minimum flow rate of ventilation, it is recommended at least a value of $12.5 \mathrm{~L} / \mathrm{s}$ per occupant, a condition that can be achieved by increasing ventilation or reducing occupation (Govierno de España, 2020). Regarding the $\mathrm{CO}_{2}$ concentration, an optimum value of $500 \mathrm{ppm}$ is indicated (Allen et al., 2020).

It is also essential to consider that the WHO advises controlling airborne transmission adequately, recommending a natural ventilation rate of at least $60 \mathrm{~L} / \mathrm{s}$ per person and six air changes per hour (World Health Organization, 2020a; World Health Organization, 2020b).
TABLE 5 | Minimum surfaces and heights in residential rooms in Spain.

\begin{tabular}{lcc}
\hline Area & \multicolumn{2}{c}{ Measurements } \\
\cline { 2 - 3 } & Minimum height (h) & Minimum surface ( $\left.\mathbf{m}^{\mathbf{2}}\right)$ \\
\hline Main room (2 pers.) & 2.5 & 10.0 \\
\hline Secondary room (1 pers.) & 2.5 & 6.0 \\
\hline Secondary room (2 pers.) & 2.5 & 10.0 \\
\hline Living room (plus kitchen) & 2.5 & $10.0(14.0)$ \\
\hline Kitchen & 2.2 & 5.0 \\
\hline Main bathroom & 2.2 & 1.5 \\
\hline Secondary bathroom & 2.2 & 1.1 \\
\hline Premises accessories & 2.2 & - \\
\hline Studio (1 pers.) & - & 25.0 \\
\hline House 1 room (up to 2 pers.) & - & 37.0
\end{tabular}

\section{Analysis of Proposals Applied to Case Studies}

For a comprehensive view of the calculation of air changes per hour, it has been necessary to verify the construction directives in Spain regarding the minimum surface area that makes up a home, also verifying the minimum net room height of housings in this country. In Spain, the dimensions of the houses are ruled by the Urban Regulations and the General Urban Planning, for each city. In this case, a comparison has been made of the regulations currently used in some cities.

According to the Urban Regulations and General Urban Planning, in most of the cities in Spain, the following parameters are expected (Table 5).

Spain is the second country in the European Union with the smallest housings, according to the latest registered data. In the last century, residential developments have been decreasing in size, with Spain being one of the countries with the smallest useful area per housing, and a large number of individual housing developments or studios have also been developed (Eurostat, 2020; Trilla Bellart, 2003).

The overcrowding of cities and the increase of the land price in the larger ones, together with the economic crisis we are undergoing in recent years, have motivated urban developments to conceive a type of housing that is increasingly smaller and with a higher degree of overcrowding (Manville and Greatbanks, 2020).

In order to evaluate all the aspects mentioned above, two dwellings are taken as case studies, in which two real situations are presented, complying with the regulations established in the Urban Regulations and the General Urban Planning.

In the first case of study, the dwelling has the minimum surfaces per room, with a total area of $45 \mathrm{~m}^{2}$ and a clear height of $2.20 \mathrm{~m}$. It has three bedrooms and an estimated occupancy of three persons.

In the second case study, the dwelling has larger surfaces in each room, with a total area of $170 \mathrm{~m}^{2}$ and a clear height of $3.00 \mathrm{~m}$. It has five bedrooms and an estimated occupancy of 10 persons.

In this way, we can analyze the ventilation parameters with two dwellings that represent extreme cases in terms of surface 


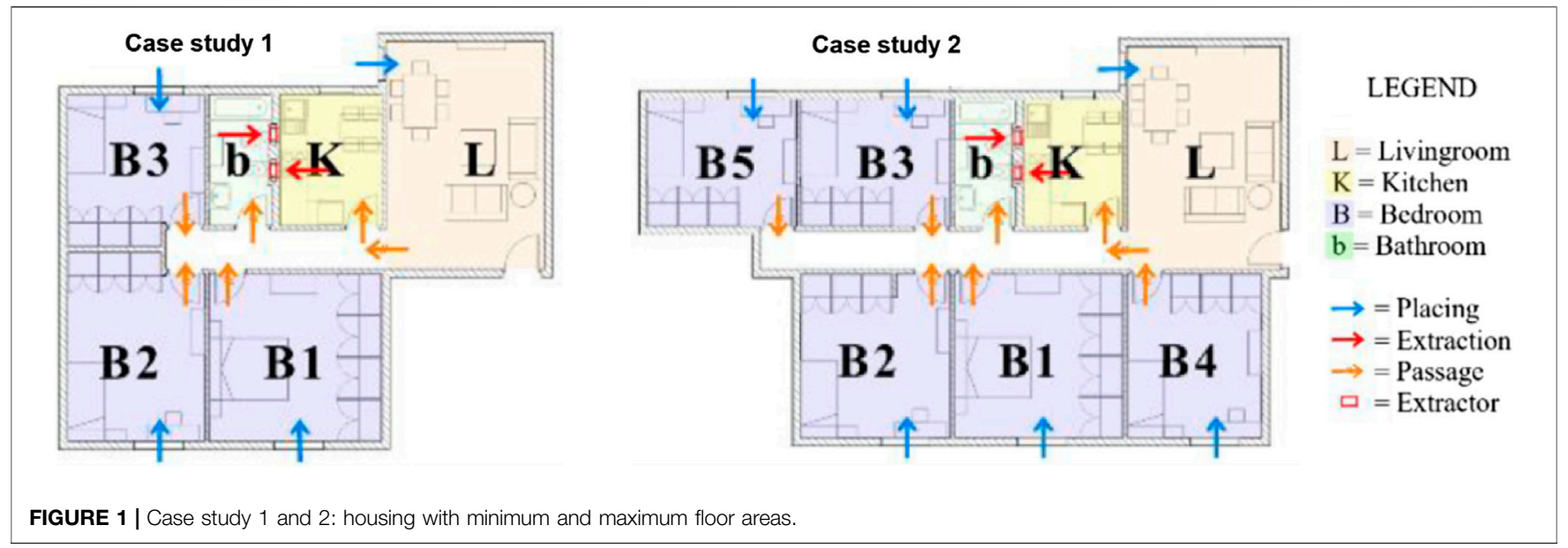

TABLE 6 | Comparison of the ventilation flow results by regulations.

\begin{tabular}{|c|c|c|c|c|c|c|c|}
\hline \multirow{3}{*}{$\begin{array}{l}\text { Case } \\
\text { study }\end{array}$} & \multicolumn{7}{|c|}{ Total ventilation flow } \\
\hline & $\begin{array}{c}\text { EN 16798-2 } \\
\text { method } 1\end{array}$ & $\begin{array}{c}\text { EN 16798-2 } \\
\text { method } 1\end{array}$ & $\begin{array}{c}\text { EN 16798-2 } \\
\text { method } 2\end{array}$ & CTE HS 3 & $\begin{array}{c}\text { Spanish } \\
\text { recommendation }\end{array}$ & $\begin{array}{r}\text { Spanish rec } \\
\text { C }\end{array}$ & tion for \\
\hline & \multicolumn{3}{|c|}{ Europe } & \multicolumn{2}{|c|}{ Spain } & \multicolumn{2}{|c|}{ World } \\
\hline & 0.49 & 0.70 & 10.00 & $\left(^{\star}\right)$ (see Table 3) & 12.50 & 60.00 & 6.00 \\
\hline & $\mathrm{I} / \mathrm{s} \mathrm{m}^{2}$ & $\mathrm{ACH}$ & I / s person & $\mathrm{I} / \mathrm{s}\left({ }^{*}\right)$ & I / s person & I/s person & $\mathrm{ACH}$ \\
\hline 1 & 22.05 & 19.25 & 30.00 & 33.00 & 37.50 & 180.00 & 165.00 \\
\hline 2 & 83.30 & 99.17 & 100.00 & 34.00 & 125.00 & 600.00 & 850.00 \\
\hline
\end{tabular}

areas and heights. The dwellings of cases 1 and 2 (Figure 1) are designed with the following formal and constructive characteristics:

In addition to these two case studies, we will analyze how surface area, volume, and number of occupants affect the flow rates established by the different regulations.

\section{RESULTS AND DISCUSSION}

The results, next discussed, indicate the influence of the chosen ventilation parameters. They are analyzed in the two case studies, as well as in a general way by the calculation parameter established by the regulations. The following sections show whether current regulations meet the new criteria established during the COVID-19 pandemic.

\section{Analysis of the Regulations on the Ventilation Flow Rate Case Study Analysis}

The data relating to category I (according to EN 16798-2) have been set as optimal. In the calculation with the European standard, a floor area of $45 \mathrm{~m}^{2}$ and an occupancy of three persons were taken in case 1 , and in case 2, a floor area of $170 \mathrm{~m}^{2}$ and an occupancy of 10 persons were taken.
The ventilation flow according to CTE HS 3 has been calculated considering three bedrooms and a living/dining room in case study 1 and five bedrooms and a living/dining room in case study 2 .

The results of the total ventilation flow rate have been obtained from the European standard and compared with the recommendation given today by the Spanish Government due to COVID-19 (Table 6).

In the case of the European standard, the method that provides the highest ventilation flow rate is the one based on the number of persons. In addition to case study 2 , the calculated air flow rates are increased by $60-70 \%$ compared to case study 1 .

In the case of the Spanish regulation, it is worth noting that the flow rates are practically the same, despite the significant differences between the two dwellings. The recommendations of the Spanish Government in times of pandemic reflect much higher and realistic ventilation flows in the current situation.

Finally, the WHO establishes very high flow rates, on the understanding that these are parameters established for high risks of contagion. In this case, the comfort of the occupants should be taken into account because these air flow rates may cause discomfort due to high air flows.

\section{General Analysis of Ventilation Flows}

Analyzing the parameters that affect the amount of flow calculated in each case, four variables need to be developed and analyzed in detail. These variables are the surface area, the 

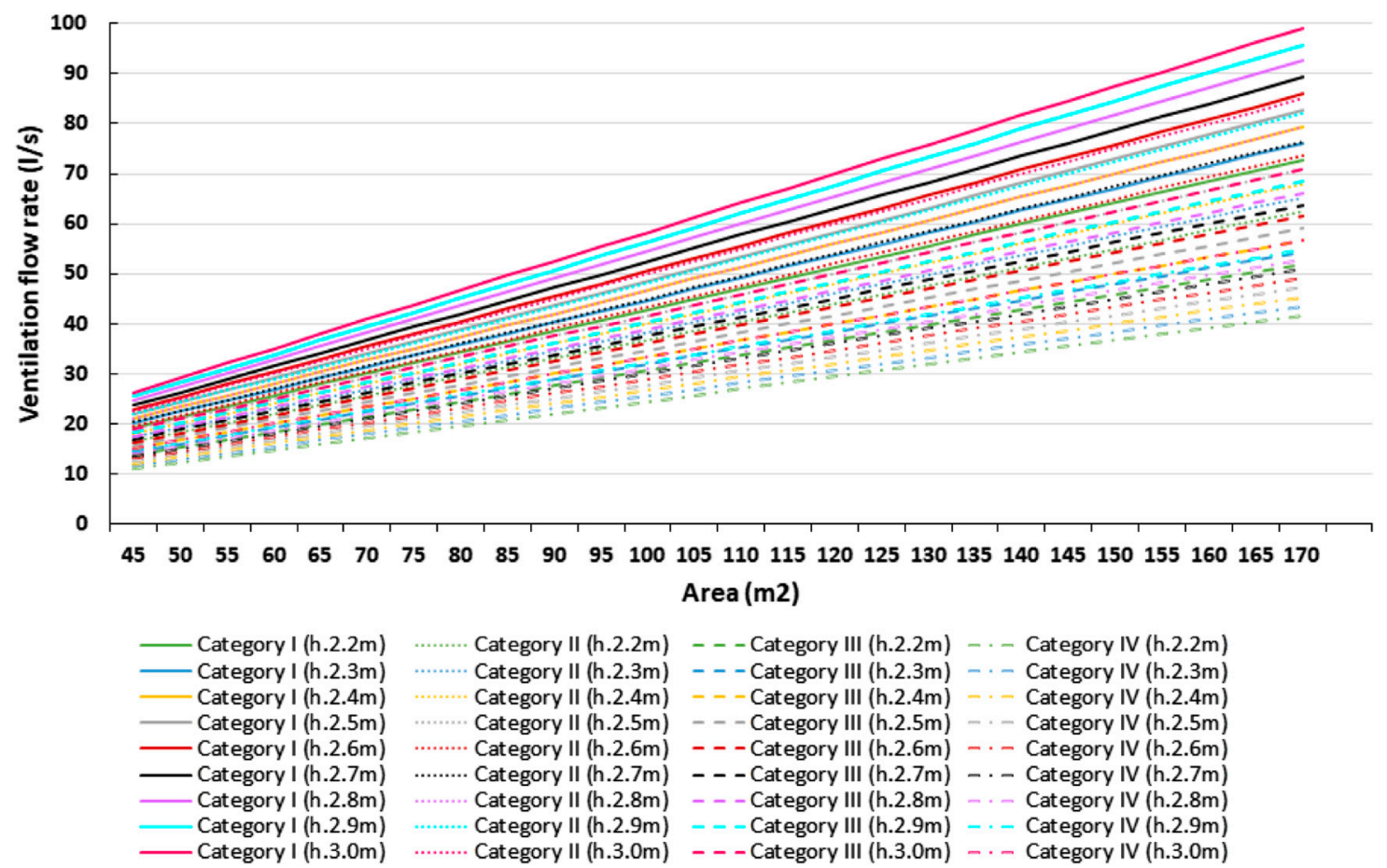

FIGURE 2 | Relationship between ventilation flow rate, floor area, and height of the house (EN 16798-2 method 1).

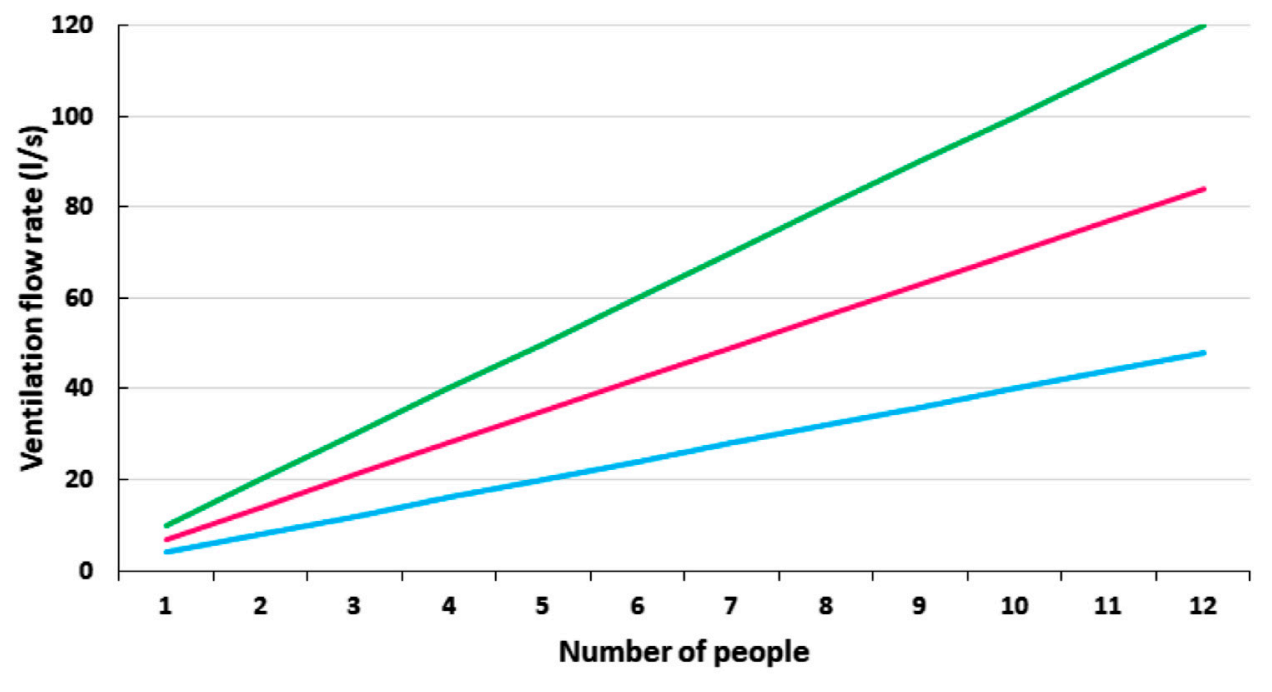

—Category I (I/s person) —Category II (I/s person) —Category III (I/s person)

FIGURE 3 | Relationship between ventilation flow rate and people (EN 16798-2 method 1).

height of the dwelling, the number of occupants, and finally, the number of bedrooms in the dwelling.

Firstly, the floor area and height are parameters that are analyzed together, according to EN 16798-2 and method 1. As shown in Figure 2, for small surfaces-around $45 \mathrm{~m}^{2}$-and heights between 2.20 and $3.00 \mathrm{~m}$, the ventilation flow rates are between $11 \mathrm{~L} / \mathrm{s}$ and $28 \mathrm{~L} / \mathrm{s}$. Conversely, when the dwelling has a larger surface area $\left(170 \mathrm{~m}^{2}\right)$, the ventilation range increases in the range between $41 \mathrm{~L} / \mathrm{s}$ and $99 \mathrm{~L} / \mathrm{s}$.

It can be seen that the height is a parameter to be taken into account, but it is not as effective as the surface area of the dwelling. In terms of air quality improvement (category I) the 
TABLE 7 | Calculation of ventilation according to Spanish regulations (CTE DB HS).

\begin{tabular}{|c|c|c|c|c|c|c|}
\hline \multirow{2}{*}{$\begin{array}{l}\text { Number of } \\
\text { bedrooms }\end{array}$} & \multicolumn{6}{|c|}{ Minimum flow $q_{v}$ in $I s^{-1}$} \\
\hline & Main bedroom & $\begin{array}{c}\text { Rest of } \\
\text { the bedrooms }\end{array}$ & $\begin{array}{l}\text { Living room } \\
\text { and dining } \\
\text { rooms }\end{array}$ & Calculated flow & $\begin{array}{l}\text { Minimum in } \\
\text { total }\end{array}$ & Final calculations \\
\hline 1 & 8 & - & 6 & 14 & 12 & 14 \\
\hline 2 & 8 & 4 & 8 & 20 & 24 & 24 \\
\hline 3 & 8 & $4+4$ & 10 & 26 & 33 & 33 \\
\hline 4 & 8 & $4+4+4$ & 10 & 30 & 33 & 33 \\
\hline 5 & 8 & $4+4+4+4$ & 10 & 34 & 33 & 34 \\
\hline 6 & 8 & $4+4+4+4+4$ & 10 & 38 & 33 & 38 \\
\hline
\end{tabular}

TABLE 8 | Comparison of $\mathrm{CO}_{2}$ concentration results by the different regulations.

$\mathrm{CO}_{2}$ concentration

\begin{tabular}{|c|c|c|c|c|}
\hline CTE DB HS 3 & $\begin{array}{l}\text { Spanish recommendation for } \\
\text { COVID-19 }\end{array}$ & $\begin{array}{c}\text { EN } 16798-2 \text { (rooms) } \\
\Delta \mathrm{CO}_{2} \text { in-out }\end{array}$ & $\begin{array}{c}\text { EN-16798-2 (living rooms) } \\
\Delta \mathrm{CO}_{2} \text { in-out }\end{array}$ & $\begin{array}{c}\text { UNE EN-171330-2 } \\
\Delta \mathrm{CO}_{2} \text { in-out }\end{array}$ \\
\hline Spain & & & Europe & \\
\hline ppm & ppm & ppm & ppm & ppm \\
\hline 900 & 500 & 380 & 550 & 500 \\
\hline
\end{tabular}

height affects more than in lower categories. In category I, between the heights of 2.20 and $3.00 \mathrm{~m}$, the increase in flow rate is $15 \mathrm{~L} / \mathrm{s}$; however, in category $\mathrm{IV}$, between the selected height range, the flow rate varies by only $5 \mathrm{~L} / \mathrm{s}$.

The analysis by one-way analysis of variance (ANOVA) showed that the surface area and the height of the dwelling present significant differences in the ventilation flow rate data, obtaining $\mathrm{F}(2.695)=10.87$, for $p<0.005$, the null hypothesis being that surface area does not significantly affect the calculation of air ventilation and rejecting this hypothesis because the value of $F$ is greater than the critical value.

The occupancy within the dwelling is also important when calculating ventilation flow rates, especially in highquality cases. In category I, from 1 person to 12 persons, the flow rate increases by $110 \mathrm{~L} / \mathrm{s}$, in category II, by $77 \mathrm{~L} / \mathrm{s}$, and in category III, by $44 \mathrm{~L} / \mathrm{s}$ (Figure 3 ).

In this case, ANOVA showed that the number of occupants of the dwelling presents significant differences in the ventilation flow rate data, obtaining $F(3.284)=6.38$, for $p<0.005$, the null hypothesis being that the number of people does not significantly affect the calculation of air ventilation and rejecting this hypothesis because the value of $\mathrm{F}$ is greater than the critical value.

According to the Spanish regulations in the CTE DB HS document, the calculation carried out based on the number of bedrooms is the most deficient because it sets very low air flow rate levels (Table 7). It would be necessary to know the square metres of each room or the number of occupants to set a value more in line with real needs. For this reason, European standards are closer to air flow rates that may be more satisfactory in terms of achieving good indoor air quality.

\section{Analysis Between the Regulations on the Concentration of $\mathrm{CO}_{2}$}

This analysis is conducted with the criteria established by European regulations, Spanish guidelines, and recommendations against COVID-19 regarding $\mathrm{CO}_{2}$ concentration (Table 8).

The Spanish regulations present very restrictive values of $\mathrm{CO}_{2}$ concentrations intramoenia, this being of $900 \mathrm{ppm}$, provided that the annual accumulated $\mathrm{CO}_{2}$ that exceeds $1,600 \mathrm{ppm}$ is less than 500,000 ppmh (Lepore et al., 2021). On the other hand, according to the recommendation guide in times of COVID-19, it is suggested that the concentration is not greater than $500 \mathrm{ppm}$. However, the European regulations EN-16798-2 and EN171330-2 present limit values depending on the internal concentration compared to the external one, having a maximum difference of approximately $550 \mathrm{ppm}$ (depending on the category). It can be seen that they are very different criteria that should be unified for the dimensioning of ventilation in homes and the improvement of people's well-being.

\section{CONCLUSION}

The ventilation flows indicated by the examined regulations and application guidelines are proven to be insufficient in times of pandemic. Therefore, the need to update them arises, due to the related risk of contagion. 
The available calculating procedures disconcert the project technician because the ventilation air flow can be calculated based on different parameters such as the surface of the house, the volume of the house, the occupation, or even the number of bedrooms. It would be necessary to establish a unique criterion to establish the parameter that best suits the results we want to obtain to have good air quality. According to the study carried out, the surface is the leading and most objective parameter, followed by the volume of the house. Occupancy is a parameter that possibly makes more sense for other activities such as public use, but not for residential use. Also, the calculation by bedroom number is not effective and adapts to reality.

Despite the low ventilation flow prescribed in Spanish regulations, the Government during the pandemic has set a more restrictive criterion of $12.5 \mathrm{~L} / \mathrm{s}$ per person due to ventilation requirements in the COVID-19 period.

As for the number of renewals per hour, the values are low for both Europe and Spain, in the case of a studio apartment lower than $2 \mathrm{R} / \mathrm{h}$ which means that it would be necessary to increase the criteria actually established by the various regulations to get closer to the $6 \mathrm{R} / \mathrm{h}$, recommended by the WHO. Regarding the concentration of $\mathrm{CO} 2$, the values that are recommended not to exceed are set around $500 \mathrm{ppm}$. Spain may present a higher risk of pollutant concentration due to smaller volumes in the different areas of the houses compared to the minimum dimensions of houses established by other countries. Therefore, in Spain, an increase of the minimum measures of health concerning house ventilation is the preferred option, seen that it is a space where people spend more hours, in light of the fact there is no available legislation that establishes optimal measures that guarantee to avoid contagion through aerosols.

As a result of this study, the need has arisen to update the legislation on ventilation, since the criteria established long ago are not currently adequate to avoid contagion by aerosols indoors. Under the proposed new paradigm, future efforts are necessary to expand this research and analyze these values with different natural and forced ventilation systems. Considering

\section{REFERENCES}

Abuhegazy, M., Talaat, K., Anderoglu, O., and Poroseva, S. V. (2020). Numerical Investigation of Aerosol Transport in a Classroom With Relevance to COVID19. Phys. Fluids 32 (10), 103311. doi:10.1063/5.0029118

Aguilera, P., Viñas, C., Rodríguez, A., and Varela, S. (2018). Análisis de la influencia, en la Demanda de Climatización, de Estrategias Pasivas en Viviendas con Grandes Superficies Acristaladas, Mediante un código de Simulación. La casa Farnsworth = Analysis of the Influence, in Climate Control Demand, of Passive Strategies in Houses With Large Glazed Surfaces, by Means of a Simulation code. The Farnsworth house. Anales de Edificación 4 (3), 34. doi:10.20868/ade.2018.3798

Aguilera-Benito, P., Varela-Lujan, S., and Piña-Ramirez, C. (2021). Thermal Behavior in Glass Houses through the Analysis of Scale Models. Sustainability 13, 7970. doi:10.3390/su13147970

Allen, J., Spengler, J., Jones, E., and Cedeno-Laurent, y. J. (2020). Guía en 5 Pasos Para Medir la Tasa de Renovación de Aire en Aulas. [Online]. Available at: https://schools.forhealth.org/wp-content/uploads/sites/19/ 2020/10/Harvard-Healthy-Buildings-program-How-to-assess-classroomventilation-10-30-2020-ES.pdf. other factors such as occupation, activity, weather conditions, and energy efficiency, it should be noted that the abovementioned results are based on simplified and ideal scenarios without taking into account many influencing factors, such as temperature, humidity, evaporation of droplets, and particles. Therefore, the results should be used with care. However, this research can be seen as an initial analysis to understand the criteria required for ventilation in residential buildings in order to address the prevention of the transmission of infectious diseases.

\section{DATA AVAILABILITY STATEMENT}

The raw data supporting the conclusions of this article will be made available by the authors, without undue reservation.

\section{AUTHOR CONTRIBUTIONS}

PB: methodology and writing. CR: drafting and formal review. $\mathrm{GV}$ : supervision and resources. EL: research and bibliographic search.

\section{ACKNOWLEDGMENTS}

The authors gratefully acknowledge the support of the ERASMUS + Traineeship and Grupo de Investigación de Tecnología y Medio Ambiente (TEMA) at the School of Building Engineering at the Technical University of Madrid.

\section{SUPPLEMENTARY MATERIAL}

The Supplementary Material for this article can be found online at: https://www.frontiersin.org/articles/10.3389/fbuil.2021.656718/ full\#supplementary-material

ASHRAE Board of Directors (2020). ASHRAE Position Document on Infectious Aerosols. [Online]. Available at: https://www.ashrae.org/file\%20library/about/ position\%20documents/pd_infectiousaerosols_2020.pdf.

Baldasano, J. M. (2020). COVID-19 Lockdown Effects on Air Quality by NO2 in the Cities of Barcelona and Madrid (Spain). Sci. Total Environ. 741, 140353. doi:10.1016/j.scitotenv.2020.140353

Balocco, C., and Leoncini, L. (2020). Energy Cost for Effective Ventilation and Air Quality for Healthy Buildings: Plant Proposals for a Historic Building School Reopening in the Covid-19 Era. Sustainability 12 (20), 8737. doi:10.3390/ su12208737

Bonadonna, L., La Rosa, G., Settimo, G., Sorrentino, E., Veschetti, E., and Bertinato, L. (2020). Indicazioni Sugli Impianti di Ventilazione/ Climatizzazione in Strutture Comunitarie non Sanitarie e in Ambienti Domestici in Relazione alla Diffusione del virus SARS-CoV-2, 1-30. [Online]. Available at: https://www.iss.it/documents/20126/0/ Rapporto+ISS+COVID-19+33_2020.pdf.

Borrelli, S. S. (2020). Politics Goes Viral as Italy Struggles with Outbreak. A Cacophony of Political Reaction Adds to Confusion in European Country Hardest Hit by Coronavirus. Available at: https://www.politico.eu/article/politics-goes-viral-asitaly-struggles-with-outbreak/ (Accessed Februaryr 25, 2020). 
CCAES (2020). Centro de Coordinación de Alertas y Emergencias Sanitarias Análisis de Situación y evaluaciones del riesgo, Ministerio de Sanidad Gobierno de España, del 1-2-2020. [Online]. Available at: https://www. mscbs.gob.es/profesionales/saludPublica/ccayes/analisisituacion/home.htm.

Coleman, J. R., and Meggers, F. (2018). Sensing of Indoor Air QualityCharacterization of Spatial and Temporal Pollutant Evolution Through Distributed Sensing. Front. Built Environ. 4, 28. doi:10.3389/fbuil.2018.00028

Darmanis, M., Çakan, M., Moustris, K. P., Kavadias, K. A., and Nikas, K.-S. P. (2020). Utilisation of Mass and Night Ventilation in Decreasing Cooling Load Demand. Sustainability 12 (18), 7826. doi:10.3390/su12187826

Dati aggregati quotidiani Regioni / PPAA (2021). Dati Aggregati Quotidiani Regioni / PPAA - Ministero Della Salute - Istituto Superiore di Sanità. [Online]. Available at: https://github.com/pcm-dpc/COVID-19.

De Gaetani, C. I., Macchi, A., and Perri, P. (2020). Joint Analysis of Cost and Energy Savings for Preliminary Design Alternative Assessment. Sustainability 12 (18), 7507. doi:10.3390/su12187507

Delibera del Consiglio dei Ministri 31 gennaio 2020 (2020). Delibera del Consiglio dei Ministri 31 Gennaio 2020, Dichiarazione dello Stato di Emergenza in Conseguenza del Rischio Sanitario Connesso all'Insorgenza di Patologie Derivanti da Agenti Virali Trasmissibili Gazzetta Ufficiale Serie Generale n.26 del 01-02-2020. [Online]. Available at: http://www.governo.it/it/ coronavirus-normativa.

Domínguez, I., Linde, P., Galocha, A., Zafra, M., Grasso, D., and Andrino, B. (2020). Spain: Over One Million Official Coronavirus Cases. Available at: https://english.elpais.com/society/2020-10-23/spain-over-one-million-officialcoronavirus-cases.html (Accessed October 23, 2020).

Dudzik, M. (2020). Towards Characterization of Indoor Environment in Smart Buildings: Modelling PMV Index Using Neural Network with One Hidden Layer. Sustainability 12 (17), 6749. doi:10.3390/su12176749

Elnikova, G. A., Nikulina, N. N., Gordienko, I. V., and Davityan, M. G. (2020). Distance Education in Universities: Lessons from the Pandemic. Eur. J. Mol. Clin. Med. 7 (1), 3253-3529. ISSN: 25158260.

Espejo, W., Celis, J. E., Chiang, G., and Bahamonde, P. (2020). Environment and COVID-19: Pollutants, Impacts, Dissemination, Management and Recommendations for Facing Future Epidemic Threats. Sci. Total Environ. 747, 141314. doi:10.1016/j.scitotenv.2020.141314

Eurostat (2020). 7 Persons Out of 10 in the EU Live in a Dwelling They Own. 2015, 7-11. [Online]. Available at: https://ec.europa.eu/eurostat/web/products-pressreleases/-/3-23112015-AP.

Filippini, T., Rothman, K. J., Goff, A., Ferrari, F., Maffeis, G., Orsini, N., et al. (2020). Satellite-Detected Tropospheric Nitrogen Dioxide and Spread of SARSCoV-2 Infection in Northern Italy. Sci. Total Environ. 739, 140278. doi:10.1016/ j.scitotenv.2020.140278

Fürhapper, C., Habla, E., Stratev, D., Weigl, M., and Dobianer, K. (2020). Living Conditions in Timber Houses: Emission Trends and Indoor Air Quality. Front. Built Environ. 5, 151. doi:10.3389/fbuil.2019.00151

Garcia-Chevesich, P. A., Alvarado, S., Neary, D. G., Valdes, R., Valdes, J., Aguirre, J. J., et al. (2014). Respiratory Disease and Particulate Air Pollution in Santiago Chile: Contribution of Erosion Particles From Fine Sediments. Environ. Pollut. 187, 202-205. doi:10.1016/j.envpol.2013.12.028

Gautam, S. (2020). COVID-19: Air Pollution Remains Low as People Stay at home. Air Qual. Atmos. Health. 13 (7), 853-857. doi:10.1007/s11869-020-00842-6

Giechaskiel, B. (2020). Gaseous and Particulate Emissions of a Euro 4 Motorcycle and Effect of Driving Style and Open or Closed Sampling Configuration. Sustainability. 12 (21), 9122. doi:10.3390/su12219122

Gilani, S., Montazeri, H., and Blocken, B. (2016). CFD Simulation of Stratified Indoor Environment in Displacement Ventilation: Validation and Sensitivity Analysis. Building Environ. 95, 299-313. doi:10.1016/j.buildenv.2015.09.010

Glass, D. H. (2020). European and US Lockdowns and Second Waves During the COVID-19 Pandemic. Math. Biosciences 330, 108472. doi:10.1016/ j.mbs.2020.108472

Gobierno de España, Ministerio de Fomento (2019). Documento Básico HS, 1-184. [Online]. Available at: https://www.codigotecnico.org/pdf/Documentos/HS/ DBHS.pdf.

Govierno de España (2020). Ministerio oara ka Transiciòn Ecològica y el Reto Demografico, IDAE, Recomendaciones de Operación y Mantenimiento de los Sistemas de Climatización y Ventilación de Edificios y Locales Para la Prevención de la Propagación del SARS-COV-2, 1-15. [Online]. Available at: https://www.mscbs.gob.es/profesionales/saludPublica/ccayes/alertasActual/ nCov/documentos/Recomendaciones_de_operacion_y_mantenimiento.pdf.

Hamdy, M., and Mauro, G. M. (2019). Optimizing Hybrid Ventilation Control Strategies Toward Zero-Cooling Energy Building. Front. Built Environ. 5, 97. doi:10.3389/fbuil.2019.00097

Heinonen, J., Säynäjoki, A., Junnonen, J.-M., Pöyry, A., and Junnila, S. (2016). Pre-use Phase LCA of a Multi-Story Residential Building: Can Greenhouse Gas Emissions Be Used as a More General Environmental Performance Indicator? Building Environ. 95, 116-125. doi:10.1016/ j.buildenv.2015.09.006

Instituto para la diversificación y ahorro de energía (2020). Sistema Climatización de Edificios y Locales Para la Prevención de la Propagación del SARS-CoV-2. [Online]. Available at: https://www.mscbs.gob.es/profesionales/saludPublica/ ccayes/alertasActual/nCov/documentos/Recomendaciones_de_operacion_y_ mantenimiento.pdf.

Jin, H.-S., Lee, S.-J., Kim, Y.-J., Ha, S.-Y., Kim, S.-I., and Song, S.-Y. (2020). Estimation of Energy Use and CO2 Emission Intensities by End Use in South Korean Apartment Units Based on In Situ Measurements. Energy and Buildings 207, 109603. doi:10.1016/j.enbuild.2019.109603

Lee, J., Park, S., and Kim, T. (2020). Development of a Ventilation System Using Window Cavity. Sustainability 12 (20), 8391. doi:10.3390/su12208391

Lepore, E., Aguilera Benito, P., Piña Ramírez, C., and Viccione, G. (2021). Indoors Ventilation in Times of Confinement by SARS-CoV-2 Epidemic: A Comparative Approach Between Spain and Italy. Sustainable Cities Soc. 72, 103051. doi:10.1016/j.scs.2021.103051

Ley 33/2011 de 4 de octubre (2011). Ley 33/2011 de 4 de Octubre, General de Salud Pública. del. 6-12-2020. [Online]. Available at: https://www.boe.es/buscar/doc. php?id=BOE-A-2011-15623.

Li, Q., Guan, X., Wu, P., Wang, X., Zhou, L., Tong, Y., et al. (2020). Early Transmission Dynamics in Wuhan, China, of Novel Coronavirus-Infected Pneumonia. New Engl. J. Med. 382 (13), 1199-1207. doi:10.1056/NEJMoa2001316

Madureira, J., Paciência, I., Rufo, J., Severo, M., Ramos, E., Barros, H., et al. (2016). Source Apportionment of CO2, PM10 and VOCs Levels and Health Risk Assessment in Naturally Ventilated Primary Schools in Porto, Portugal. Building Environ. 96, 198-205. doi:10.1016/j.buildenv.2015.11.031

Manville, G., and Greatbanks, R. (2020). Performance Management in Hybrid Organisations: A Study in Social Housing. Eur. Management J. 38 (3), 533-545. doi:10.1016/j.emj.2020.04.006

Ogen, Y. (2020). Assessing Nitrogen Dioxide (NO2) Levels as a Contributing Factor to Coronavirus (COVID-19) Fatality. Sci. Total Environ. 726, 138605. doi:10.1016/j.scitotenv.2020.138605

Ordinanza del Ministro della salute 30 gennaio 2020 (2020). Ordinanza del Ministro Della Salute 30 Gennaio 2020, Misure Profilattiche Contro il Nuovo Coronavirus (2019 - nCoV), Gazzetta Ufficiale Serie Generale n.26 del 01-02-2020. [Online]. Available at: http://www.governo.it/it/coronavirus-normativa.

Pulimeno, M., Piscitelli, P., Colazzo, S., Colao, A., and Miani, A. (2020). Indoor Air Quality at School and Students' Performance: Recommendations of the UNESCO Chair on Health Education and Sustainable Development \& the Italian Society of Environmental Medicine (SIMA). Health Promot. Perspect. 10 (3), 169-174. doi:10.34172/hpp.2020.29

Rapporto Istituto Superiore della Sanità (ISS) (2020). COVID-19 n. 20/2020 Rev. 2, Indicazioni Ad Interim per la Sanificazione Degli ambienti Interni nel Contesto Sanitario e Assistenziale per Prevenire la Trasmissione di SARS-CoV-2, 1-20. [Online]. Available at: https://www.iss.it/rapporti-covid-19/-/asset_publisher/ btw1J82wtYzH/content/id/5371609.

Rossi, R., Ceccato, R., and Gastaldi, M. (2020). Effect of Road Traffic on Air Pollution. Experimental Evidence From COVID-19 Lockdown. Sustainability 12 (21), 8984. doi:10.3390/su12218984

Sironi, S., Eusebio, L., Capelli, L., Remondini, M., and Del Rosso, R. E. (2014). Use of an Electronic Nose for Indoor Air Quality Monitoring. Chem. Eng. Transaction 40, 73-78. doi:10.3303/CET1440013

Spiteri, G., Fielding, J., Diercke, M., Campese, C., Enouf, V., Gaymard, A., et al. (2020). First Cases of Coronavirus Disease 2019 (COVID-19) in the WHO European Region, January 24 to February 21 2020. Euro Surveill. 25 (9), 2000178. doi:10.2807/1560-7917.ES.2020.25.9.2000178

Sun, C., and Zhai, Z. (2020). The Efficacy of Social Distance and Ventilation Effectiveness in Preventing COVID-19 Transmission. Sustainable Cities Soc. 62, 102390. doi:10.1016/j.scs.2020.102390 
Trilla Bellart, C. (2003). La Política de vivienda en una perspectiva europea comparada, Revista de economía y finanzas de Castilla y León. La Rioja: (Mercado inmobiliario y política de vivienda), 33-52. ISSN 1139-6865, N. 6.

UNE-EN 15251 (2008). Parámetros del Ambiente Interior a Considerar Para el Diseño y la Evaluación de la Eficiencia Energética de Edificios Incluyendo la Calidad del Aire Interior, Condiciones Térmicas, Iluminación y Ruido (Módulo 1-6). [Online]. Available at: https://www.une.org/encuentra-tu-norma/buscatu-norma/norma?c=N0041732.

Urrutia-Pereira, M., Mello-da-Silva, C. A., and Solé, D. (2020). COVID-19 and Air Pollution: A Dangerous Association? Allergologia et Immunopathologia 48 (5), 496-499. doi:10.1016/j.aller.2020.05.004

Viccione, G., Spiniello, D., Zarra, T., and Naddeo, V. (2014). Fluid Dynamic Simulation of Odour Measurement Chamber. Chem. Eng. Transaction 40, 109-114. doi:10.3303/CET1440019

Viccione, G., Zarra, T., Giuliani, S., Naddeo, V., and Belgiorno, V. (2012). Performance Study of E-Nose Measurement Chamber for Environmental Odour Monitoring. Chem. Eng. Transaction 30, 109-114. doi:10.3303/CET1230019

Voss, T., and Wittwer, J. (2020). Unterricht in Zeiten von Corona: Ein Blick auf die Herausforderungen aus der Sicht von Unterrichts- und Instruktionsforschung. Unterrichtswiss 48 (4), 601-627. doi:10.1007/s42010-020-00088-2

Woodby, B., Arnold, M. M., and Valacchi, G. (2020). SARS-CoV-2 Infection, COVID-19 Pathogenesis, and Exposure to Air Pollution: What Is the Connection? Ann. N.Y. Acad. Sci. 1486, 15-38. doi:10.1111/nyas.14512

World Health Organization (2005). WHO Air Quality Guidelines for Particulate Matter, Ozone, Nitrogen Dioxide and Sulfur Dioxide: Global Update. 2005, 1-21. [Online]. Available at: https://apps.who.int/iris/ handle/10665/69477.

World Health Organization (2020a). Gestión de la COVID-19 en Hoteles y Otras Entidades del Sector del Alojamiento. [Online]. Available at: https://apps.who. int/iris/bitstream/handle/10665/334128/WHO-2019-nCoV-Hotels-2020.3spa.pdf.
World Health Organization (2020b). Consideraciones Para la Cuarentena de los Contactos de Casos de COVID-19. [Online]. Available at: https://apps.who.int/ iris/bitstream/handle/10665/333968/WHO-2019-nCoV-IHR_Quarantine-2020.3spa.pdf? sequence $=1$ \&isAllowed $=y$.

Yao, X., Dewancker, B. J., Guo, Y., Han, S., and Xu, J. (2020). Study on Passive Ventilation and Cooling Strategies for Cold Lanes and Courtyard Houses-A Case Study of Rural Traditional Village in Shaanxi, China. Sustainability 12 (20), 8687. doi:10.3390/su12208687

Zoran, M. A., Savastru, R. S., Savastru, D. M., and Tautan, M. N. (2020). Assessing the Relationship between Ground Levels of Ozone (O3) and Nitrogen Dioxide (NO2) With Coronavirus (COVID19) in Milan, Italy. Sci. Total Environ. 740, 140005. doi:10.1016/ j.scitotenv.2020.140005

Conflict of Interest: The authors declare that the research was conducted in the absence of any commercial or financial relationships that could be construed as a potential conflict of interest.

Publisher's Note: All claims expressed in this article are solely those of the authors and do not necessarily represent those of their affiliated organizations, or those of the publisher, the editors, and the reviewers. Any product that may be evaluated in this article, or claim that may be made by its manufacturer, is not guaranteed or endorsed by the publisher.

Copyright (C) 2021 Aguilera Benito, Piña Ramírez, Viccione and Lepore. This is an open-access article distributed under the terms of the Creative Commons Attribution License (CC BY). The use, distribution or reproduction in other forums is permitted, provided the original author(s) and the copyright owner(s) are credited and that the original publication in this journal is cited, in accordance with accepted academic practice. No use, distribution or reproduction is permitted which does not comply with these terms. 